Original scientific paper

\title{
HOW TO OFFER THEORETICAL SOLUTION FOR PRACTICAL ORGANIZATIONAL PROBLEMS - CASE STUDY
}

Peter HARMATH, PhD, Lecturer

Faculty of Economics in Subotica,

Address: $\quad$ Segedinski put 9-11, 24000 Subotica, Serbia

Phone: $\quad+38124628057$

Email: $\quad$ harmatp@ef.uns.ac.rs 


\title{
HOW TO OFFER THEORETICAL SOLUTION FOR PRACTICAL ORGANIZATIONAL PROBLEMS - CASE STUDY
}

\section{Key words:}

Organizational theory, organizational diagnosis, Contingency theory, Life cycle of organizations,

\begin{abstract}
:
Establishing an organization, setting it on track of development is becoming a more and more complicated task and in most cases, requires expert knowledge. Scientific organizational theory offers a great variety of applicable methods and tools for small and young enterprises as support for their design and development. The performed case study is based on consultancy work at local Business Incubator in Subotica.

This article presents the author's approach, examination and description of some of the most common problems of small enterprises. A number of organizational theoretical terms were considered and have been connected with the specific case. The basic aim of the project was to solve a set of actual organizational problems for one of the business incubator tenants. The analyzed group of problems were related to the structural design of an organization (e.g. existing simple structure vs. functional), division of labor, job design, decentralization, delegation, formalization and standardization, and span of control.

The applied methods were based on classical organization theory, contingency theory, Adizes life cycle of organizations, and other different partial approaches. Far from the full set of factors that an up-to-date contingency survey uses, this article considers only a few aspects with special focus on small enterprises and their typical symptoms. While the task was successfully completed, it seems this combined approach lends proof to the problem solving possibilities of such methodical approach of applying organizational theoretical knowledge in practice.
\end{abstract}

\section{INTRODUCTION}

Organizational problem solving possibilities are widely discussed in literature on management and organization. Usually problems are mentioned as subjects of change activities (such as major or main organization tasks and accessory tasks). Of course these problems or tasks for organizations are not the same. There are generally highly analyzable and lowly analyzable tasks. The classification of these tasks is case sensitive and very often depends on the theoretical background of the engaged experts. Usually, low analyzability tasks are difficult to solve and require the problem solvers to use judgment, instinct, intuition, and experience rather than programmed solutions. Some counterproductive norms can focus the decision-maker's attention on the simple issues, often the things one can measure quantitatively rather than the crucial issues - frequently these are the blockages to change and improvement (Hodge, 2003). At any rate, it is advisable to use or consider more theoretical approaches and techniques meantime to solve the practical problems. The lack of a clear and holistic viewpoint can cause blindness toward the problems of organization (Kieser, 1995). Thus it is advisable to use wider argumentation for the basic terms of organization. While classical management theorists such as Taylor and Fayol were looking 
for the single best way in management and organization design, in the late $50 \mathrm{~s}$ and early $60 \mathrm{~s}$ a shift of paradigm arose, claiming that the organizational structure of a company or administration has to fit to the situation in which it finds itself. In today's variable situations the different structures turn out to be most effective. In other words the optimal organizational structure is contingent, depending on certain contextual factors. Therefore the Contingency Approach is included in the practical case study. Different researchers used to focus on different contextual factors and measure their influence in empirical studies.

Considering the basic organizational properties and contingencies in addition with other attributes according to the organizational science glossary one can offer as a useable approach to problem analyzing. Organization theory is a diverse field and involves 'pluralism' (Reed \& Hughes, 1992) or 'paradigm war' (McKelvey, 1997) depending on the perspective. As a theoretical background of this article some other empirically-oriented contingency theory was added such as Burton \& Obel's approach (Burton \& Obel, 1998, 2005). They justify the adoption of this theoretical foundation on the basis that it has been developed sufficiently to provide a comprehensive set of internally consistent propositions or rules. "The contingency or situational approach recognizes that organizational systems are inter-related with their environment and that different environments require different organizational relationships for the effective working of the organization" (http://www.fao.org/docrep/W7503E/w7503e03.htm)

While the contingency approach was used to analyze contingency design fit solutions and organizational properties, the included Adizes Life Cycle Assessment approach was applied to make the case more comprehensive.

Whether in an external or internal consulting role, the participation of the client in all phases of the improvement process is a key factor to success. In respect of this role, the methodology was based on interviews and applied questionnaires according to the program OrgCon ${ }^{1}$ (Burton, Obel, 1998), Step by Step Approach (Burton, De Sanctis \& Obel, 2006) and Adizes on line Life Cycle Assessment ${ }^{2}$. (Adizes, 2010 a,b,)

\footnotetext{
${ }^{1}$ The program "OrgCon" based on contingency approach expert system (Burton, Obel, 1998) provides a tool for diagnosis and design. It aids the design process by asking the designer questions about the current organization, the contingency factors, and then offers recommendations on the design, the configuration and the properties. (Zhiang Lin, 2011.)

${ }^{2}$ The Adizes Lifecycle Assessment Survey instantly produce and present a customized web report that contains a graphical representation and written summary of the lifecycle stage(s) of analysed company. The custom report is based on clients answers to a series of questions (www.Adizes.com)
} 


\section{MATERIALS AND METHODS}

Complex organizational problems are made simpler when they are separated into smaller, more understandable elements. That is why this shortened case study is based on the consideration of the crucial theoretical organizational terms. The selection of the right analysis tool depends on the nature of the problem. The list of cited terms guided the author to analyze and describe some of the most typical problems of small and young enterprises. The article describes one of the consultancy works completed in Business Incubator in Subotica. The basic aim was to solve the obvious and very typical problems of one of the small and young enterprises. Its case could be described as representative for the majority of firms in high rate of growth without named and delegated functions, lacking formal structure and formalization. According to the results of the initial enquiry (interview with the owner manager), this client - after a short period of being in the "Go-Go phase" it derailed towards the phase called "The founder's trap" (Adizes, 2010a). The consultancy work started with the questions (basic terms) about the range of contingency factors including:

- Size/Ownership

- Management Style

- Organizational Climate

- Environment

- Technology

- Strategy.

And about the organization and its current situation are listed "organizational properties and structural configurations" (Burton, Obel, 1998) e.g.

- Organization's current configuration (organizational structure - form),

- Complexity (vertical, horizontal, spacial differentiation),

- Centralization and decentralization

- Formalization,

- Incentives, ...

As a matter of fact it is the problem finding stage that can be called the strategic assessment. The problem finding and problem formulation stages are also part of the 
organizational audit. Special emphasis was laid on problems or typical symptoms that may occur in any of the small enterprises.

One of the possible patterns for analyzing these terms can be followed according to organizational (diagnosis and) design using a "Step by Step approach" (Burton, De Sanctis, Obel, 2006).

We "should start by assessing two, always existing, fundamental goals, efficiency and effectiveness. Efficiency is a primary focus on inputs, use of resources, and costs. Effectiveness is a focus more on outputs, products or services and revenues. These are competing priorities. Some organizations place a higher priority on efficiency, focusing on minimizing the costs of producing goods or services. Other organizations emphasize effectiveness focusing on generating revenues or seizing leading-edge innovation in the marketplace.” (Burton, De Sanctis, Obel, 2006)

Based on the given answers and interviews the current organization's features could be summarized according to the highlighted terms. Meantime we can consider some theoretical recommendations pertinent to the current case).

\section{RESULTS}

\section{The strategy of the organization}

Before starting to analyze structural questions, one should know about the famous dictum "structure follows strategy" (Chandler, 1962). One of the simple but powerful ways to describe a firm's strategy is in terms of reactor, defender, prospector and analyzer with and without innovation. (Miles \& Snow, 1978) Situational contingencies influence the strategies, structures, and processes. There is always more than one way to reach a goal but in any case managers should adapt their organizations to the situation. Most likely the client's (studied case) strategy is a defender because it has greater focus on exploitation than on exploration. That means defender is high on exploiting its resources and situation but low on exploring anything new or being innovative. The defender should maintain its position by being efficient much more than the competitors. The defender is slow to make significant change. This can lead to a dangerous position in some environmental circumstances. An organization with a defender strategy is an organization with a narrow product market domain. Top managers in this type of organization are experts in their organization's limited area of operation but do not tend to search outside their domains for new opportunities. In an uncertain environment, it is very likely that the customers will prefer variation in 
products and services. Competitors are likely to vary their strategies in products, prices, advertising, etc. New innovative strategies may be called for.

Usually an organization in the "Go-Go phase is a company that has a successful product or service, rapidly growing sales and strong cash flow". (http://www.adizes.com/corporate_lifecycle_gogo.html)

The Go-Go companies are sales and opportunity-driven rather than opportunity-driving. They react rather than proact to opportunities.

Everything is described as a business priority. To make matters worse, often the overloaded manager has difficulty articulating his strategy and ideas clearly. (In the client's firm evidently bad sign predicting misfits). The employees who can interpret the Founder's ideas become the key person, critically important insiders. They may become trusted and authorized confidants in future.

\section{The business environment}

Open systems theory can be defined as a theory of organization that views organizations dependable from their surroundings, highly complex entities facing considerable uncertainties in their operations and constantly interacting with their environment. The environment creates limits and opportunities for a firm's strategy and structure with other organizational properties. This system also assumes that organizational components will seek equilibrium among the forces pressing on them and their own responses to their forces. The organization's environment can be described in numerous ways. For this case the four dimensional environmental description will do. A) The environmental complexity which is the number of factors in the environment, and their interdependency. B) The environmental uncertainty which is the variance among the factors. C) The environmental equivocality which is the ignorance and confusion about the existence of some factors. D) The environmental hostility which is the extent of malicious external threats.

In the examined period of time the client's business environment can be described as a medium equivocality, medium uncertainty, and high complexity. In this stage it is important to consider: does the strategy fit the firm's goals. If it does not fit the goal, the statement should be reconsidered or the strategy to fit with the goals. Second: does the strategy fit the environment? Generally the aim (in the case of such a small firm) is to move the organization's strategy to fit the environment. 


\section{The size of the organization}

One of the most widely accepted measures for organizational size is the total number of full-time or full-time-equivalent employees. With the 12 employees the consulted firm can be considered as a small enterprise. Some approaches define the adjusted size e.g. define correction factors according to the employee's level of education. Between 51 and $75 \%$ of the people employed by the client have a high level of education. But in this case the possible adjustments do not mean change. This enterprise is a typical small privately owned firm (a bit over the size of the so-called micro firm).

\section{Organizational structure}

It is sometimes called configuration or architecture, frequently pictured as an organizational chart. It shows the principles of departmentalization identifies the grouping together of functions or individuals, hierarchy - number of levels and the span of control, formal communication patterns - coordination, and integration. A poorly designed structure may cause a number of misfits between the organizational properties and contingency factors. The contingency theory of organizations posits that there is no single best way to organize. The optimum structure for an organization depends on the values of variables describing its task and environment. The organizational structure must provide adequate support for the position and effectively. That means sufficient authority, resources and management support. All of the job overlaps should be avoided as a source of inefficiency and conflicts.

According to the scheme - organizational chart given, it was easy to recognize that the client's organization had a typical Simple Structure. That can be characterized as a structure with low degree of departmentalization and a wide span of control. The authority is largely centralized in a single person with very little formalization. It usually has only two or three vertical levels, so it could be called 'flat structure', and means low vertical differentiation. Human resources are a flexible set of employees, and generally one person in whom the power of decision-making is invested. This simple structure is most widely practiced in small business settings where the manager and (usually the) owner happens to be the same person. Its advantage lies in its simplicity. This makes it responsive, fast, accountable and easy to maintain. However, it becomes grossly inadequate as and when the organization grows in size. Such a simple structure is becoming popular because of its flexibility, responsiveness and high degree of adaptability to change. Go-Gos need continuous restructuring. They are like children who keep outgrowing their clothes. Many Go-Go 
leaders however attribute little importance to structure, managerial processes or systems. They are focused externally on the sales. Organizational structures, roles, responsibilities, require attention to detail, discipline and self-restraint. These qualities are quite alien to the entrepreneur". (http://www.adizes.com/corporate_lifecycle_gogo.html)

\section{Question of organizational complexity}

The complexity of organization is measured by vertical (hierarchical), horizontal, and spatial (geographical) differentiation. In most of the cases an organization's hierarchy (vertical differentiation) begins to emerge when the organization experiences problems (very often connected with the question of delegation). A basic design challenge involves deciding how much authority to centralize at the top of an organization and how much to decentralize to middle and lower levels.

Small organizations should have low organizational complexity. The client has a routine technology, which implies that the organizational complexity should be low. When the environmental hostility is high, organizational complexity should be low. The top manager has a preference for a high level of involvement into decision making in lower (operative) level, which leads to lower organizational complexity. It is also a symptom that appears in the Go-Go's founder trap.

"When the size of the company and the environmental complexity increases, the top of the simple structure usually may get overloaded with information". This information overload may compromise the effectiveness of the decision-making performed at the organizational top, and make the organization slower in its adaptation to new situations. Growing companies, in changing and dynamic environments, may therefore need to specialize and formalize its organizational structure, so that work must not be as heavily coordinated by the organizational top. Likewise, companies may need to differentiate activities into subtasks, and employ specialists responsible for a given subtask previously handled by e.g. the company owner. Finally, companies may need to decentralize some of the decision-making power to lower levels of the organization, so that decisions are made by people responsible for the subtask, and who controls specific knowledge and information about the handling of the given subtask. A clear pattern of vertical and horizontal differentiation can cut down on role conflict and role ambiguity". (http://www.businessmate.org/Article.php?ArtikelId=183)

"Organizational differentiation means the un-bundling and re-arranging of activities. Regrouping and re-linking them is organizational integration (Lawrence \& Lorsch, 1967). 
When different units are assigned individual tasks and functions, they set independent goals" also. (http://www.fao.org/docrep/W7503E/w7503e03.htm)

\section{Organizational climate}

Organizational climate is a measure of internal environment and can be described in terms of the values of a particular set of characteristics or attitudes of the organization. It is experienced by its members. It refers to all members of the organization including superiors and subordinates. Basically the climate can be described with two dimensions: A) Tension incorporates a combination of organizational factors as experienced by insiders such as trust, conflict, morale, rewards, leader credibility and scapegoating. B) Readiness to change - people's readiness to shift direction or adjust their work habits. For more precise diagnosis the four category models as a combination of the mentioned dimensions seems to be applicable. (Table 1.)

Table 1 Organizational climate dimensions

\begin{tabular}{|l|l|l|l|l|}
\hline & \multicolumn{1}{|c|}{ Group } & Internal process & \multicolumn{1}{c|}{ Developmental } & \multicolumn{1}{c|}{ Rational goal } \\
\hline Tension & Low & High & Low & High \\
\hline $\begin{array}{l}\text { Readiness to } \\
\text { change }\end{array}$ & Low & Low & High & High \\
\hline oriented & Internally & Internally & Externally & Externally \\
\hline
\end{tabular}

Abridged from: Burton M.R. DeSanctis G., \& Obel B. (2006) p. 149.

Based on the answers provided for analyses, it is most likely that the client's organizational climate is a developmental climate. "The developmental climate is characterized as a dynamic, entrepreneurial and creative place to work. The leaders are considered to be innovators and risk takers. Readiness for change and meeting new challenges are important. The organization's long-term emphasis is on growth and acquiring new resources. Success means having unique and new products or services and being a product or service leader is important. The organization encourages individual initiative and freedom". (Orgcon Report Summary according to the case)

\section{The management style}

Managers have to perform many roles in an organization and how they handle various situations will depend on their style of management. According to the applied approach (OrgCon questionnaire - Burton, Obel, 1998) the management style can be measured by the level of management's micro-involvement in decision making. Leaders could have a low or high preference for micro-involvement. As a matter of fact, it means that there are two 
sharply contrasting styles: Autocratic and Permissive. (http://www.rpi.edu/dept/advising/ free_enterprise/business_structures/management_styles.htm, 31.08.2011.)

In the current case the manager has a high preference for micro-involvement. It could be considered as a typical example for small firm around Go - Go phase. The authority presents itself as the power vested in a person by virtue of his role to expand resources: financial, human and technical, in order to meet the accountabilities of the role. It is very important to have a clear and distinct line of authority among the positions in an organization so-called "Chain of command".

The manager of the reviewed company has a preference for making most of the decisions himself. This means a high preference for micro-involvement. When the Manager has a preference for using control to coordinate activities that leads toward a high preference for micro-involvement. Founder - manager needs employee's deep feelings of affection and respect.

\section{Delegation and decentralization}

Decentralization is a necessary and continuous process which means systematically delegating power and authority throughout the organization to middle and lower-level managers. It goes together with the delegation process by which a manager assigns a portion of his or her total workload to others.

The manager is "often ineffective (and frustrated). With his personal involvement in the day-to-day work of the company, the leader often has little time to manage. Work is hastily assigned with scant attention to detail". As a matter of fact the owner does not need to be involved in all those details. This is a real sign (distinctly appeared in this case) that there is a need for decentralization. Some founders view these symptoms as further evidence that successful business depends on their personal engagement. The usual problem is that they tend to fix these problems by taking personal control (and unnecessary level of microinvolvement). "The employees are frustrated. In the face of an overwhelming workload, unclear responsibilities and fuzzy goals, employees find it increasingly difficult to be productive. New people are hired and thrown into their jobs with little training or preparation. Physical space and proper equipment can be scarce because growth is difficult to predict. Promotions can occur on the spur of the moment. Later in adolescence it often turns out that people promoted into senior management positions during previous phase do not have the skills and experience needed to succeed in that position." (http://www.adizes.com/corporate_lifecycle_gogo.html) Often when the rules and policies 
are created the founder - leader could be the first to violate them. In the Go-Go phase founders also tend to struggle with delegation and decentralization. Workable decentralization requires an effective system of control. Mistakes in delegating can bring the Founder to retake the reins of control. It can endanger the process of effective decentralization. The Founder needs to escape day-to-day details so that he can focus on the whole picture.

If perpetuated, this inability to effectively delegate will threaten organization in Go-Go phase into a premature aging syndrome known as the "Founder's Trap" (Adizes, 1990). (See figure 1.) It occurs when a rapidly growing company is unable to relieve itself from dependency on the founder. With weak control systems, accountability is very unclear no one takes responsibility. This is the stage where "everyone claims inadequate information, lack of authority, and feels they are the victims of decisions made by other people. Fingers point in all directions. This frustrates Go-Go leaders. They feel betrayed. No one warned them of the tricky dangers ahead". (http://www.adizes.com/corporate_lifecycle_gogo.html)

The urgent need is uncovered to develop functions and abilities needed between employees to replace the unique skills of the owner. If it will not happen because the owner manager is unwilling or unable to effectively delegate and decentralize control, it can become a fatal problem.

Fig. 1 "Go - Go phase" turning into dangerous "Founder trap"

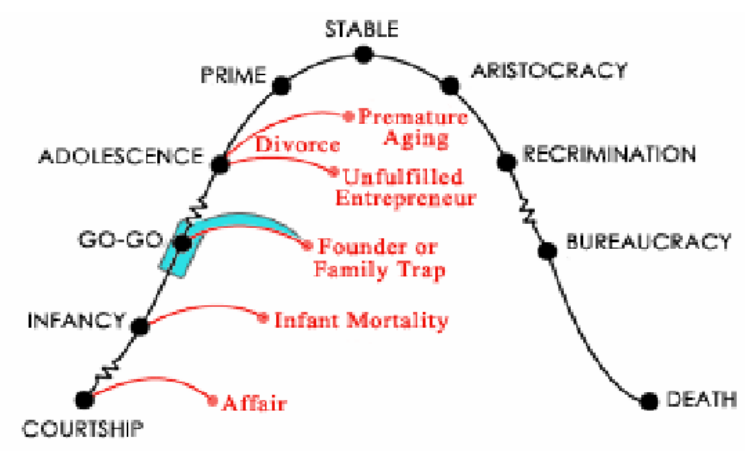

Adizes Organizational Lifecycles ${ }^{T M}$

Source: (Adizes I., 2010 b.) a customized web report

\section{Integration and coordination}

It involves the collaboration among specialists needed to achieve a common purpose of the organizational sub-systems. It evolves some controlling mechanisms for smooth functioning of the organization. As a matter of fact, it means organizational counterbalance for decentralization differentiation and (in some cases) division of labor. Integration can be 
achieved across various specialized units, functions to ensure that organizational goals are being pursued. "Span of control refers to the number of specialized activities or personnel supervised by one manager. There is no optimal number for a span of control and number of levels in the hierarchy. In fact, span of control and hierarchy levels are inter-related and depend on situational factors" (Barkdull, 1963). Important features to be considered while designing are: similarity and complexity of functions, need for direction and control, managerial coordination and planning requirement.

There are several methods to improve integration. (If needed, even in a small organization). These include rules and procedures and professional training. Communication is another important process in the organization crucial for achieving integration and coordination of the activities of separated units at different levels. Communication can be horizontal, downward or upward. Integration and coordination refer to integration of the objectives and activities of specialized units or sub-systems in order to achieve the organization's overall strategic objectives. In large and complex organizations coordination and integration become extremely important It can also be improved through developing rules and procedures, and professional training (done simultaneously), with professional committees involving managers from different specialized units.

Integration aims at ensuring that different sub-systems work towards common goals. Staff meetings with the purpose of integration and coordination are held weekly in short duration for each work group (department), with the general manager present. There are no meetings for the entire staff meantime.

Some additional terms of analysis were

- Job design - "...the assignment of goals and tasks to be accomplished by employees..."

- Job enrichment - "An alternative to job specialization (that) which involves increasing both the number of tasks (job enlargement) the worker does and the control the worker has over the job become crucial too for the examined firm." (Daft, 2006).

\section{Technology}

Technology is based on major activity. In the current case it is production (a unit production technology - finished products from composite material, custom-made furniture). The client only has (a) few different products, operates in one country, has a low product and process innovation, with a high concern for quality. "In an uncertain environment, it is very likely that the customers will prefer variation in products and services. Competitors are 
likely to vary their strategies in products, prices, advertising, etc. New innovative strategies may be called for. Some rather non-routine technology will likely be required to adapt to an uncertain environment." (Burton, Obel, 1998 b)

In this organization Information and accounting systems seemed to be weak. This can be typical for Go-GO phase) where only support for basic needs of production/operations, customer service and accounting exists. The client's firm lacks useful cost accounting and accurate reporting of individual product profitability. Management reports are often published so late that they are of little use for day-to-day operations. (Insufficient cost controls, ad hoc budgeting)

\section{The question of formalization}

Formalization is the degree to which an organization has rules, procedures, and written documentation. Formalization means an organization is involving installation and use of rules, procedures, and control systems.

The examined firm is organized around people and projects. Responsibilities are assigned based on who can do the work on a project-by-project (product - task) basis. New tasks often conflict with previous assignments. Often the organization chart does not accurately reflect the way work really gets done.

\section{DISCUSSION}

\section{Strategic design recommendations}

According to the cited literature and applied practice knowledge the results of the performed analyses show comparisons between the theoretical input modules and identified appropriate practical organizational solutions. The basic aim was to diagnose and solve the fundamental discrepancies between contingency factors and elements of organizational properties. As a result some of the identified values of major factors and properties in the analyzed organization derailed from universal principles of management and contingencies, that means urgent adjustment is needed in the client's firm.

When many factors in the environment affect the organization, it may make it difficult for a defender like the client's firm to protect what it does and also difficult to protect its established market position. Therefore, the defender strategy is not appropriate. An analyzer strategy is more appropriate for this complex environment. Here the analyzer should seek out opportunities in the complex environment. 
The current organizational complexity is low. Understandably due to the fact that it is a small firm with medium horizontal differentiation, low vertical and low geographical differentiation. (It is only in one location).

The most likely configuration that best fits the situation for the client has been estimated to be a functional configuration. A functional organization is an organization with unit grouping by functional specialization (production, marketing, finance, etc.).

The current formalization is medium but there should be high formalization between the organizational units but less formalization within the units due to the high professionalization. Since the firm employs many professionals the formalization should not be as high as it would otherwise be. When the organization is in the manufacturing industry and it has a routine technology, its formalization should be lower than if it were in the service industry. When the organization uses an advanced information system, formalization should be high. A defender strategy needs cost efficiency and that can be obtained through formalization. Organizations with routine technology should have high formalization. High formalization is consistent with top management's preference for a high level of microinvolvement.

The organizational life cycle phase "The Founder's Trap" (uncovered pathologies for Go-Go) "occurs when a Go-Go company is unable to relieve itself from its dependency on the Founder. The company is trapped by the capabilities and limitations of the bottleneck that is its Founder. This can occur because the organization is unable to develop the abilities needed to replace the unique skills of the Founder. The slide into the "Founder's Trap" can also occur because the Founder himself is either unwilling or unable to delegate effectively and decentralize control. Developing the skills, systems, trust and respect needed to support delegation and decentralization is a crucial task for the given client. The process starts with delegation from the Founder, which involves transferring responsibility for important tasks down into organization and creating the commitment needed to achieve the desired results. But, forcing this transition before it can be effectively supported will foster mistrust and animosity between the Founder and the employees" (the future senior management team), and exacerbate the Founder's "Trap" pathology. (http://www.adizes.com/ corporate_lifecycle_gogo.html) Go-Go companies must begin to make the transition from management-by-intuition to a more professional approach. Stage of Founder's trap should be avoided by staggered empowerment. That can be achieved through:

- aligned role with capability, 
- aligned tasks with the role,

- aligned resources with accountability,

- context or value provided by the manager.

Consistent human resource management builds responsibility, enables avoiding confusion in roles and frustration of employees.

The motivational system should develop a feeling of obligation in employees and also the system of values, standards, conscience and aspirations that individual demands of himself or herself. It relates to one's own standards, conscience, values and aspirations.

Incentives should be based on results and procedures. The client's coordination and control should be based on rules and procedures, integrators could be group meetings and some mutual planning. Unannounced and unproductive meetings should be avoided. A moderate amount of information will be required and it is not likely that there will be a need for rich information (nor for wide channels of information).

On the field of formalization the current client should consider increasing the number of positions for which written job descriptions and written rules and procedures are available. According to the defined measures the supervising of the employees should be closer.

\section{CONCLUSION}

One of the major misfits that created obvious problems was the un-adjusted (defender) strategy with the business environment and organizational climate. The reason lies in the lack of delegation and decentralization. The pathological Go-Go's "founder trap phase" spontaneously formed because of the overloaded owner's inability to form and control strategy. It slowed down the process of growth, derailed the organizational forces, such as creativity, and led to the diagnosed "founder trap". This stage threatens healthy development; it cannot be maintained over a longer period. Missing adequate organizational structure with poorly defined division of labor additionally worsens the situation. Very often "a single misfit may make the whole design unacceptable". (Burton, Lauridsen, Obel, 2002)

The detected situation shows misfits in a routine technology and uncertain environment because it can cause problems. For this contingency some non-routine technology is better! "A routine technology produces goods and services efficiently which are standard and without variation. Low product innovation but a certain environment calls for a review and suggests that the organization consider greater product innovation. Low product innovation 
means that the same products are available for an extended period of time. In a certain environment with little change in customer demands and preferences, there is little need for new products. But, with increasing uncertainty in customer demand, new competitor strategies, possible governmental actions, shifting customer tastes, etc., current products are likely to become soon mismatched with the possibly changed environment. New products and innovation will likely be required to adapt and meet the emerging needs and opportunities of the new business environment" (Burton, Obel B, 1998 b)

It is evident that the client's firm needs to make the recommended interventions to return on the fastest possible track of development.

Such simplified approach, showed in the article can give a model that would assist analysts to deal with more widely recognized factors. The majority of those considered organizational glossary terms should be considered when diagnosing and designing organizations of any type and in any contingency circumstances. Users are asked to identify organizational design parameters in order to change their settings (if necessary). In this case the majority of important contingencies have been identified. It is also shown that the selected and analyzed terms can provide wider and guided possibilities for organizational analyses in even more complex situations. The suggested model of thinking or qualitative analytical approach may be applicable to the majority of managerial issues.

\section{Summary}

Establishing an organization, setting it on track of development is becoming a more and more complicated task and in most cases, requires expert knowledge. Scientific organizational theory offers a great variety of applicable methods and tools for small and young enterprises as support for their design and development. The performed case study is based on consultancy work at local Business Incubator in Subotica. Because as a management consultant, the basic role or challenge was to identify and investigate problems connected with the case and to control implementation of the recommended actions.

Organizing becomes crucial managerial function of arranging people and resources to work toward a goal. The purposes of organizing include, but are not limited to determining the tasks to be performed in order to achieve objectives, dividing tasks into specific jobs, grouping jobs into departments, specifying reporting and authority relationships, delegating the authority necessary for task accomplishment.

The study is written with the aim to offer a theoretic approach to solving the rising empirical problem of organization, giving the model of thinking for comprehension of diversity when designing - creating, restructuring organizational architecture typical for small enterprises.

This article presents the author's approach, examination and description of some of the most common problems of small enterprises. A number of organizational theoretical terms were considered and have been connected with the specific case. The basic aim of the project was to solve a set of actual organizational problems for one of the business incubator tenants. The analyzed group of problems were related to the structural design of an organization (e.g. existing simple structure vs. functional), division of labor, job design, decentralization, delegation, formalization and standardization, and span of control.

As an uninvolved person (only in the role of a consultant) the task was also to overview the potential processes of derailment in application of prescribed treatment. (E.g. Not to allow the management to gradually leave the necessary change process, to audit if the necessary additional efforts were made to reduce the occasional 
resistance that risks the main objectives to disappear. Not to allow only cosmetic changes to happen but making insufficient effort to forward the process of the needed change).

The applied methods were based on classical organization theory, contingency theory, Adizes life cycle of organizations, and other different partial approaches. This expanded approach involves mechanistic and morganatic viewpoints too. Organisations can become sick, just as people do. Like people, organisations can be structurally sick or behaviourally sick. The various "symptoms" can be studied, hopefully, within a diagnostic framework that would enable an accurate diagnosis to be made and treatment prescribed to bring about a healthy, productive and successful organisation. In this article some comparisons are made between human maladies and organisational problems between medical and "organisational diagnosis". This kind of "organic" approach shows some new possibilities in studying the organisational effectiveness and "health".

The selected methods give us an opportunity to uncover some of the extremely dangerous misfits (e.g. inappropriateness of strategy and goals, configuration, organizational climate, leadership style, etc. The basic aim was to diagnose and solve the fundamental discrepancies between contingency factors and elements of organizational properties in order to find the best possible total design fit. The process of diagnosis has uncovered that some of the identified values of major factors and properties in the analyzed organization derailed from universal principles of management and contingencies, that means urgent adjustment was needed in the client's firm.

Far from the full set of factors that an up-to-date contingency survey uses, this article considers only a few aspects with special focus on small enterprises and their typical symptoms. The contingency views as part of the leading theoretical approach of organizational design help us consider some aspects relevant in analyzing conditions of strategy formation and its influences on structure and organization "health" (fitted to be fit). These contingency factors include external and internal environment, management style, climate, size and ownership, technology, and properties of organization such as complexity and differentiation, formalization, centralization, span of control, rules, procedures, flow of information - media richness, incentives, etc). It is assumed that the characteristics of strategy and other market devices correlate with specific contents of the contingency factors for organizational structure as well as with properties and structural configuration of the organization.

The purpose of this research was achieved. With the described approach we obtained a powerful tool, strong enough to enable the manager (the client) to merge diverse elements of their small enterprises, learn to make successful combination for functioning in new structural design, and controllability.

The study offers a managerial toolkit for the business person or consultant who wants to make his or her organization better. Direct focus was on design, supported by the science of organization theory, which provides the basis for the diagnosis and design. While the task was successfully completed, it seems this combined approach lends proof to the problem solving possibilities of such combined methodical approach of applying organizational theoretical knowledge in practice.

\section{Summary in Hungarian}

\section{MIKÉNT ADJUNK ELMÉLETI MEGOLDÁSOKAT GYAKORLATI SZERVEZETI PROBLÉMÁKRA - ESETTANULMÁNY}

A vállalatok megalapítása és a fejlődés irányába fordítása egyre inkább összetett feladattá válik, és az esetek többségében szakértői tudást igényel. A tudományos szervezetelmélet az alkalmazható eszközök, módszerek széles skáláját kínálja. A kis és középvállalkozások projektálasa és fejlesztése esetén is. A bemutatott esettanulmány a szabadkai ügyviteli inkubátorban végzett tanácsadói (konzultáns) munka eredménye. Menedzsment konzultánsként az alapvető feladat illetve kihívás a szervezeti problémák feltárása kivizsgálása és a javasolt megoldások alkalmazásának ellenőrzése volt.

A célok elérése érdekében a menedzsment funkciók között kulcsfontosságúvá vált a szervezés. A szervezés céljai leginkább, nem szúkítve azok körét, a szükséges feladatok meghatározását, csoportosítását, egységekbe tagosítását, jog -körök és felhatalmazások kialakítását jelenti.

A tanulmány azzal a céllal íródott, hogy elméleti megközelítést - modellt kínáljon az egyre növekvő és sokasodó gyakorlati szervezési problémák megoldásához, a kis és középvállalatok kialakításánál és átszervezésénél.

A cikkben a szerző néhány a kis és középvállalatokra legjellemzőbb problémának a megközelítését és vizsgálatát mutatja be. Számos szervezetelméleti kifejezés - fogalom lett figyelembe véve a konkrét eseten 
keresztül. A (konzultáns) projekt célja néhány szervezeti probléma megoldása volt az ügyviteli inkubátor egyik (albérlő - ügyfél) cégénél. Az elemzett problémák a szervezeti konfiguráció kérdésére (a meglevő egyszerü struktúra vagy a helyette kialakítandó funkcionális struktúrára) munkamegosztásra, munkakörök leírására, decentralizációra, delegációra, szabványosításra, ellenőrzési fesztávra vonatkoztak.

Külső résztvevőként (csak a konzultáns szerepében) a feladat még az esetleges eltérések felügyelete és a javasolt megoldások alkalmazásának ellenőrzése is volt. (Például: nehogy a menedzsment fokozatosan letérjen a szükséges átalakítási folyamatról, ellenőrizni vajon megtették-e a kellő erőfeszítéseket az esetleges ellenállások felszámolásához melyek kockáztathatják a alapvető célok, megvalósítását. Nem szabad megengedni a látszólagos változtatásokat vagy nem kielégítő intézkedéseket a szükséges változtatások végrehajtásánál.)

Az alkalmazott módszerek klasszikus szervezetelmélet, kontingencia - elmélet, a szervezetek Adizes szervezeti életciklus, illetve más részleges megközelítéseken alapultak. Ez a kiszélesített megközelítés magába foglalta a mechanisztikus és az organikus aspektusokat is. Mint ahogy az emberek a vállalatok is megbetegedhetnek, szervileg azaz strukturálisan vagy mentálisan magatartásukban. A különböző tünetek segíthetik a pontos diagnózis felállítását és a megfelelő gyógymód meghatározását egy egészséges, termékeny (termelékeny) és sikeres szervezetet érdekében. Ebben a cikkben néhány összehasonlítást tehetünk az orvosi és a szervezeti diagnózis között, az emberi betegségek és a szervezeti problémák között. Ez a szerves megközelítés bevezet néhány új lehetőséget a szervezeti hatékonyság és egészség tanulmányozásában.

A kiválasztott módszerek lehetőséget adtak arra, hogy felfedődjenek rendkívül veszélyes szervezeti körülmények (a stratégia és a célok, a konfiguráció, a szervezeti klíma, a vezetői stílus, stb. összehangolatlansága. Az elsődleges cél a kontingencia - tényezők és a szervezeti jellemzők alapvető ellentmondásainak diagnózisa, majd teljes egyeztetése, azaz a szervezeti összhang kialakítása volt. A szervezeti diagnózis felállításának folyamata több ellentmondást is feltárt, (például eltéréseket az általános menedzsment elvektől) és e körülmények sürgős egyeztetést (beavatkozást) igényeltek a megbízó cégénél.

A kontingencia - elmélet teljes eszköztárától eltekintve, a cikk csak néhány a kisvállalatok tipikus tüneteire szempontjaira összpontosít. A kontingencia - elmélet a szervezetek tervezésénél segíti néhány fontos feltétel körülmény elemzését. Ilyenek a stratégia megalkotása és a szervezet egészsége („testre szabott egészség”). E kontingencia - tényezők magukban foglalják a: külső és belső környezetet, vezetői stílust, szervezeti klímát, a vállalat nagyságát, tulajdonviszonyokat, technológiát. Ezen túl felöleli az egyéb szervezeti jellemzőket, mint, a komplexitás, a differenciálódás, formalizálás, központosítás, ellenőrzési fesztáv, feladatkörök és folyamatok, az információ keringése (csatornái), a motiváció, stb. Feltételezhető, hogy a stratégia és a piac jellegzetességei összefüggnek (korreláltak) a kontingencia - tényezőkkel, ugyanúgy ahogy a struktúrával vagy a szervezet többi jellemzőivel is.

A kutatás célja megvalósult. A leírt megközelítéssel egy hathatós eszközt biztosítottunk mely lehetővé tette a menedzsernek (az ügyfélnek), hogy egyeztesse (összehangolja) kisvállalkozásának különböző elemeit, és müködőképes irányító struktúráját sikeressé tegye.

A tanulmány vezetői irányítói eszköztárat kínál a menedzsereknek vagy a tanácsadóknak, akik jobbá szeretnék alakítani vállalataikat. Így a közvetlen figyelem a szervezetelmélet által biztosított tudományos szervezeti diagnózisra és tervezésre irányult. Mivel a feladat sikeresen meg lett oldva, úgy tűnik, hogy ez a kombinált szervezetelméleti tudás bizonyítottan megoldást nyújthat a gyakorlati alkalmazásban is.

\section{Kulcsszavak:}

Szervezetelmélet, szervezeti diagnózis, kontingencia elmélet, a szervezetek életciklusa,

\section{REFERENCES}

Adizes I., (1990), Corporate Lifecycles: How and Why Corporations Grow and Die and What to Do About It, Prentice Hall

Adizes, I., (2004), Managing Corporate Life Cycles, (2nd ed.), Santa Monica, Adizes Institute.

Adizes, I. (2007), Upravljanje životnim ciklusima preduzeća, ASEE, Novi Sad

Adizes I, (2010 a) The Corporate Lifecycle. Retrieved Oct. 10, 2010. from http://www.adizes.com/corporate_lifecycle_overview.html 
Adizes, (2010 b,)Understanding the Corporate Lifecycle, An Instant Online Lifecycle $\begin{array}{llll}\text { Analysis } & \text { Retrieved } & \text { Oct.15, } & \\ & & \end{array}$ http://www.adizes.com/lifecycle_assessment_form.html

Adizes I., (1998), The Adizes Program CD Rom, A Compedium to the thought and practice of one of the world's top management authors and practicioners, Illuminate Publications.

Barkdull, C.W., (1963): Span of Control: A Method of Evaluation, Michigan Business Review 15 May p 25-32.

Burton M. R. \& Obel, B., (1998). Strategic Organizational Diagnosis and Design, Boston, Kluwer Academic Publishers.

Burton M. R. \& Obel, B., (2005), Strategic Organizational Diagnosis and Design, The Dynamics of Fit, (3rd ed.), New York, Springer.

Burton M.R. DeSanctis G., \& Obel B. (2006), Organizational Design, A Step By Step Apporoach, Cambridge university press, New York, ISBN: 052161733 2.page 11.

Burton, M. R. \& Lauridsen, J. \& Obel, B. Return on Assets Loss from Situational and Contingency Misfits, Management Science, Vol. 48, No. 11, November 2002, p.1480.

Burton, R., Obel, B., (1998 b) OrgCon program CD, (Fully working educational sofware version), Case sensitive - Report Summary, Ecomerc.

Burton, R., Obel, B., (2005, b) OrgCon program CD, $3^{\text {rd }}$ ed., (Educational sofware version) Case sensitive - Report Summary, Springer

Chandler, A. D., (1962), Strategy and Structure Chapters in the History of the Industrial Enterprises, Cambridge, MA, MiT Press.

Daft L R., (2006), Organization Theory and Design, 9tth ed., Thomson south Western p. 595.

FAO Corporate Depository, Management of agricultural research. Module 3 Session 1. http://www.fao.org/docrep/W7503E/w7503e03.htm, retrieved 15 Oct. 2011.

Hodge, B.J., Anthony, W. P. \& Gales, L. M., (2003), Organization Theory a Strategic Approach, 6th ed. New Jersey, Prentice Hall.

Kieser, A., (1995). Szervezetelmeletek, Aula, Budapest, p 2.

Lawrence, P.R., \& Lorsch, J.W. (1967), Differentiation and integration in complex organizations. Administrative Science Quarterly, June: 1-47.

McKelvey B., (1997), Quasi-Natural Organization Science. Organization Science, 8:p.352380.

Miles, R.E. \& Snow, C.C. (Jul., 1978), Organizational Strategy, Structure, and Process,The Academy of Management Review, Vol. 3, No.3, p. 546-562

ReeD M. I., Hughes M., (editors1992.), Rethinking Organization: New Directions in Organization Theory and Analysis, Sage, London.

Zhiang Lin Book Review http://www.ecomerc.com/content/reviews/zhianglin, retrieved $10^{\text {th }}$ Oct. 2011 